\title{
The Competency Assessment Model for Public Transport Drivers based on the Indonesian National Qualifications Framework (KKNI) uses Analytical Hierarchy Process
}

\author{
Nur Kumala Dewi \\ Facultyof Computer, STMIK Muhammadiyah Jakarta, Jakarta,Indonesia \\ ${ }^{*}$ Corresponding Author: \\ Email:nkd.mandori@gmail.com
}

\begin{abstract}
.
This driver behavior assessment model discusses the expertise of public transport drivers based on the national Work Qualification with graduate competency standards (SKL). Graduate competency standards have parameters, namely competence, competency elements and graduation indicators. From these three parameters, the competency unit is abbreviated as UK, the competency element is abbreviated as EK, and the graduation indicator is abbreviated as IK. Assessment of the first competency unit is upon attitudes and values, the second competency unit is upon the ability in the field of work, the third competency unit isupon the area of knowledge mastered and the fourth competency unit is upon the rights and responsibilities. The first competency unit has 6 competency elements and 6 graduation indicators, the second competency unit has 27 competency elements and 41 graduation indicators, the third competency unit has 6 competencies and 11 graduation indicators, the fourth competency unit has 2 competency elements and 4 graduation indicators. The first unit is abbreviated as UK1, the first competency element is abbreviated as EK1, while for the first indicator of graduation is abbreviated as IK1. The combination of UK1, EK1 and IK1 becomes UK1EK1. The combination of the first competency unit becomes the first competency element and combined to become the first graduation indicator then becomes UK1IK1, and so do the next competency unit up to the fourth competency unit. The completion stages of this discussion is carried out in four steps, namely problem identification, model design, implementation and system evaluation. The calculation process uses Analytic Hierarchy Process (AHP).
\end{abstract}

Keywords: Driver, Kompentesi, KKNI, AHP.

\section{INTRODUCTION}

The behavior of drivers in public transportation is variety: some are good, polite and others are not good[1]. Drivers have the potential to cause accidents, unsafe, disorderly in traffic. Traffic accidents certainly have an adverse impact on society[2], from the point of view of comfort, order and smoothness of traffic. Driving without experience is one of the main predictors of accident rate. The higher accident rate among young drivers is due to poor cognitive[3]. One of the solutions to reduce traffic accidents is to have a driver competency standard. Driver competency standards based on the Beginner Level II Indonesian National Qualification Framework (KKNI) have 3 parameters, namely competency units, competency elements, and graduation indicators. With this solution, the handling ofdriver's problem is expected to be improved[4], so that passengers will feel safe, comfortable and orderly in using public transportation[5].

\section{LITERATUR REVIEW}

A driver is a person who drives a motorized vehicle on a road with an obligation of having a driving license. However, it is not yet efficient and effective to overcome the public transportation, as still occur in some underdeveloped areas where we can find drivers with high ego driving on the roads, plus with uneven mass transportation distribution, which this problem often occurs in the archipelago region[6]. For this reason, the 
Ministry of Transportation is now developing 12 ports in the province of North Sumatra. The high use of private vehicles because the integration of the public transportation sectors is not built yet. Lack of infrastructure and transportation facilities, there is no system that can break the use of private vehicles, while there is a number of services and facilities that pamper private vehicle users, the problem of air pollution, vibration pollution, noise pollution which cause theconditions of public transport poorly maintained, low level of driver awareness, lack of road's allocation management are the factor of traffic accidents. Transportation problems in Indonesia are categorized into 4 categories, namely congestion, accidents, chaos, pollution[7]. There is a lot of thuggery, lack of government attention, many people on the road, not all drivers understand the traffic regulation, lack of attention to the driver's social security, people dress untidy, lack of personal hygiene, communication problem, carelessness of driving, even prone to harm passengers or others road users[8]. The number of traffic accidents involving public transport vehicles put the driver as the main cause. Taking this into account, road traffic safety should naturally become a national priority which needs to be improved urgently. The results of the research showed that negligence in recognizing situations and negligence in making action taken decisions in driving were the dominant factors in human error[9]. The results of the research showed that the variables related to safety driving practices were knowledge, attitudes, safety briefings, participation in safety driving training and the role of supervisors, while the variables that were not related to safety driving practices were age, years of service, and the role of coworkers[8]. Based on daily phenomena, seen that many motorists violating the traffic signs. This behavior of violating traffic signs is an example of aggressive driving behavior that can harm other road users. The results of the research showed that there was a relationship between length of work, rest time, work schedule and unsafe driving. The model presented in this research shows that strategies to improve organizational safety culture can reduce the behavior of unskilled drivers and thus reduce the number of accidents. The results of the researchshowed that the main factors that influence driver performance that cause accidents are health, discipline, and driver competence. The behavior of young male drivers in Saudi Arabia is classified into three categories: making mistakes, driving aggressively and driving fast[11]. Aggressive and fast driving behavior has a significant effect on accident. Driving attitudes and skills are significant factors affecting driver accidents in China[9]. The behavior of drivers in China can become safer if their skills can be improved and their attitudes towards traffic safety are changed. Drivers in Norway demonstrate that there is a significant relationship between driver training, traffic safety attitudes and driving behavior. There is a strong relationship between accident and exposure (measured as months holding a license). The involvement of newly young drivers is related to driving skills and safety attitudes and driver behavior. This research aims to calculate the most significant driver behavior factors that have a critical impact on road safety[12]. The well-proven Analytical Hierarchy Process (AHP) was applied to the 20 driver behavior factors examined in a three-level hierarchical structure. The predicted results suggested that road management authorities should focus on significant highlevel driver behavior criteria to solve road safety problems for sustainable traffic safety. Identifying and categorizing driver behavior using the Fuzzy Analytic Hierarchy Process (FAHP) can resolve the uncertainty of driver behavior[10]. Test the driver behavior criteria that significantly affect safety for different traffic cultures such as in Hungary, Turkey, Pakistan and China. The FAHP framework for comparing and measuring driver behavior criteria is designed on a three-level hierarchical structure. Proper description of driver behavior and evaluation with its context is a key factor for the efficient driving learning process[13]. The results of the research showed that a series of patterns designed to evaluate the application of driving techniques can identify the wrong actions of the driver, so it can make recommendations to improve driver performance. In this research, a hybrid of Discrete Wavelet Transformation (DWT) and Adaptive Neuro Fuzzy Inference System (ANFIS) is used to identify overall driving behavior. These behaviors are classified into safe, semi-aggressive, and aggressive classes which are adopted by self-reported questionnaire results by the Driver Anger Scale (DAS)[11]. This research introduces a concept proposal to access driving behavior in public transport through Mobile Crowd Sensing (MCS), as part of a long-term research project on Advanced Public Transportation 
System (APTS). The proposed concept uses a mobile device accelerometer and a qualitative evaluation of passengers to identify aggressive driving behavior[14], which is believed to be a major factor in the occurrence of accidents and unnecessary fuel consumption. Conceptually, each qualification level in the IQF is composed of six main parameters, namely (a) science, (b) knowledge, (c) practical knowledge (know-how), (d) skills, (e) affection and (f) competency. The six parameters contained in each level are arranged in the form of a description called a Qualification Descriptors. In the field of driving a motorized vehicle, there are several provisions that become references related to the preparation of SKL, namely. 1. Legislation of the Republic of Indonesia Number 22 of 2009 concerning Road Traffic and Transportation 2. National General Safety Plan (RUNK) 3. Presidential Instruction Number 4 of 2013 concerning the Road Safety Action Decade program 4. KAPOLRI Regulation Number 9 of 2012 concerning Letters of Driving Permit[12]. SKL is a qualification standard for graduation abilities that includes attitudes, knowledge, and skills as stipulated in Kepmendiknas Number 23 of 2006. This is important so that students who have received training truly gain competence as motorized vehicle drivers. The IQF-based Graduate Competency Standards are stated by three parameters, namely: 1. Competence: Competence is the accumulation of a person's ability to carry out a measurable job description through a structured[16], independent and responsible assessment in the work environment. The Element of Competency: a detailed competency statement 3. Graduation indicators: elements as the parameter to measure the success of a graduated studentwhether is competent or not, for SKL competency standards are in table.1,2,3,4[13].

Table 1. Attitude and values (UK1)

\begin{tabular}{|c|c|c|c|}
\hline \multicolumn{4}{|c|}{$\begin{array}{c}\text { COMPETENCY STANDARD GRADUATES BASED ON KKNI FOR } \\
\text { DRIVING PROFESSION LEVEL II BEGINNERS }\end{array}$} \\
\hline NO & CompetencyUnit & ELEMENTS OF COMPETENCE & PASS INDICATOR \\
\hline \multicolumn{4}{|c|}{ ATTTTUDES AND VALUES } \\
\hline \multirow[t]{6}{*}{1} & $\begin{array}{l}\text { Build and shape the } \\
\text { character and } \\
\text { personality of } \\
\text { Indonesian people }\end{array}$ & $\begin{array}{l}\text { a. Fear God The One and Only } \\
\text { The One and Only }\end{array}$ & $\begin{array}{l}\text { a) Always be vigilant in running the } \\
\text { vehicle } \\
\text { b.) Be polite in driving }\end{array}$ \\
\hline & & $\begin{array}{l}\text { b. Have good morals, ethics and } \\
\text { personality in completing their } \\
\text { duties }\end{array}$ & $\begin{array}{l}\text { c) Has no impact } \\
\text { which endangers passengers and other } \\
\text { road users }\end{array}$ \\
\hline & & $\begin{array}{l}\text { c. Play a role in realizing good } \\
\text { ethics and personality as citizens } \\
\text { who are proud and love the } \\
\text { country and support world peace }\end{array}$ & $\begin{array}{l}\text { d) Comply with the prevailing traffic } \\
\text { rules and regulations } \\
\text { e) Honest at work }\end{array}$ \\
\hline & & $\begin{array}{l}\text { d. Able to work together and have } \\
\text { social sensitivity and high } \\
\text { concern for society and the } \\
\text { environment }\end{array}$ & f) Being a pioneer of road safety \\
\hline & & $\begin{array}{l}\text { e. Respect the diversity of cultures, } \\
\text { views, beliefs, and religions and } \\
\text { respect the original opinions / } \\
\text { findings of others }\end{array}$ & \\
\hline & & $\begin{array}{l}\text { f. Upholding law enforcement and } \\
\text { having the spirit to put interests } \\
\text { first }\end{array}$ & \\
\hline
\end{tabular}


Table 2. Ability in the field of work (UK2)

\begin{tabular}{|c|c|c|}
\hline \multicolumn{3}{|c|}{ Ability in the field of work } \\
\hline \multirow{7}{*}{$\begin{array}{l}\text { 1. Able to drive and } \\
\text { control motorized } \\
\text { vehicles } \\
\text { independently by } \\
\text { prioritizing traffic } \\
\text { safety and security }\end{array}$} & $\begin{array}{l}\text { a. Prepare for the operation of } \\
\text { motorized vehicles and } \\
\text { identify eligibility } \\
\text { vehicle: }\end{array}$ & \\
\hline & $\begin{array}{l}\text { 1) Identifying the completeness of } \\
\text { motor vehicle certificates }\end{array}$ & $\begin{array}{l}\text { Accuracy in identifying the } \\
\text { completeness of motorvehicle } \\
\text { documents }\end{array}$ \\
\hline & $\begin{array}{l}\text { 2) Identifying and using basic } \\
\text { equipment } \\
\text { motorvehicle }\end{array}$ & $\begin{array}{l}\text { Accuracy in identifying and using basic } \\
\text { motor vehicle equipment }\end{array}$ \\
\hline & $\begin{array}{l}\text { 3) Identifying and using } \\
\text { vehicle cleaning tools } \\
\text { and materials according } \\
\text { to their designation }\end{array}$ & $\begin{array}{l}\text { Accuracy in identifying and using } \\
\text { vehicle cleaning tools and materials } \\
\text { according to their designation }\end{array}$ \\
\hline & $\begin{array}{l}\text { 4) Identifying indicators and } \\
\text { checking the feasibility } \\
\text { of a motorized vehicle } \\
\text { engine components }\end{array}$ & $\begin{array}{l}\text { Accuracy identifies indicators and } \\
\text { components of the feasibility of a } \\
\text { motorized vehicle engine (electrical and } \\
\text { transmission instruments, oil, cooling } \\
\text { water, wiper water, brake system and } \\
\text { steering system) }\end{array}$ \\
\hline & $\begin{array}{l}\text { 5) Identify ing roadworthiness } \\
\text { indicators for the outside } \\
\text { of motorized vehicles }\end{array}$ & \\
\hline & $\begin{array}{l}\text { b. Drive and control } \\
\text { motorized vehicles in an } \\
\text { efficient and } \\
\text { environmentally } \\
\text { friendly manner by } \\
\text { complying with } \\
\text { regulations and }\end{array}$ & \\
\hline
\end{tabular}

Table 3. Master Knowledge (UK3)

\begin{tabular}{|c|c|c|}
\hline \multicolumn{3}{|c|}{ Mastered Knowledge } \\
\hline \multirow[t]{6}{*}{$\begin{array}{l}\text { Mastering } \\
\text { knowledge } \\
\text { procedural, factual, } \\
\text { principles about } \\
\text { vehicles and light } \\
\text { driving techniques } \\
\end{array}$} & $\begin{array}{l}\text { a. Mastering knowledge of } \\
\text { driving ethics }\end{array}$ & $\begin{array}{l}\text { a) Implementing traffic ethics in } \\
\text { accordance with applicable } \\
\text { regulations } \\
\text { b) Obey traffic signs and signals with } \\
\text { right }\end{array}$ \\
\hline & $\begin{array}{l}\text { b. Mastering specifications, } \\
\text { instruments and indicators } \\
\text { on vehicles }\end{array}$ & $\begin{array}{l}\text { a) Distinguishing vehicle } \\
\text { specifications properly } \\
\text { b) Using instruments properly } \\
\text { c) Understand indicators } \\
\text { on the vehicle }\end{array}$ \\
\hline & $\begin{array}{l}\text { c. Understand the principles } \\
\text { and techniques of } \\
\text { operating motorized } \\
\text { vehicles that are conomical } \\
\text { and environmentally } \\
\text { friendly }\end{array}$ & $\begin{array}{l}\text { Have knowledge of speed regulation, } \\
\text { engine speed, wind pressure related to } \\
\text { the principles and techniques of } \\
\text { operating an economical and } \\
\text { environmentally friendly motor } \\
\text { vehicle }\end{array}$ \\
\hline & $\begin{array}{l}\text { d. Understand the rules and } \\
\text { traffic safety, health and } \\
\text { safety work in a vehicle }\end{array}$ & $\begin{array}{l}\text { Implement regulations and traffic } \\
\text { safety, health and safety } \\
\text { work in driving }\end{array}$ \\
\hline & $\begin{array}{l}\text { e. Understand factual knowledge } \\
\text { about the conditions and } \\
\text { principles of service for } \\
\text { children, pregnant women, } \\
\text { the elderly, people with } \\
\text { disabilities and passengers } \\
\text { with needs other specialty }\end{array}$ & $\begin{array}{l}\text { Carry out procedures and actions in } \\
\text { accordance with the principles of } \\
\text { service for children, pregnant } \\
\text { women, the elderly, people with } \\
\text { disabilities and other passengers } \\
\text { with special needs }\end{array}$ \\
\hline & $\begin{array}{l}\text { f. Understand the procedures } \\
\text { for making SIM, vehicle } \\
\text { insurance, life insurance and } \\
\text { other vehicle documents }\end{array}$ & $\begin{array}{l}\text { a) Carry out the procedure for } \\
\text { making SIMA } \\
\text { b) Carry out insurance management } \\
\text { procedures } \\
\text { c) Carry out procedures for } \\
\text { handling documents Vehicle } \\
\text { others }\end{array}$ \\
\hline
\end{tabular}


Table 4. Rights and Responsibilities (UK4)

\begin{tabular}{|c|c|c|}
\hline \multicolumn{3}{|c|}{ Rights and Responsibilities } \\
\hline $\begin{array}{l}\text { Responsible as a } \\
\text { driver in terms of } \\
\text { personal safety and } \\
\text { security for drivers, } \\
\text { passengers and other } \\
\text { road users and can be } \\
\text { given the } \\
\text { responsibility of } \\
\text { guiding prospective }\end{array}$ & $\begin{array}{l}\text { a. Responsible for his job as a } \\
\text { driver }\end{array}$ & $\begin{array}{l}\text { a) Carry out the task of driving a } \\
\text { motorized vehicle without any } \\
\text { errors } \\
\text { b) Maintain the vehicle in } \\
\text { accordance with maintenance } \\
\text { procedures } \\
\text { c) Record and communicate every } \\
\text { important event in running his } \\
\text { job }\end{array}$ \\
\hline novice drivers & $\begin{array}{l}\text { b. Can be given the } \\
\text { responsibility of guiding } \\
\text { candidates novice driver }\end{array}$ & $\begin{array}{l}\text { Describe safety standards and basic } \\
\text { techniques running the vehicle }\end{array}$ \\
\hline
\end{tabular}

\section{RESULT AND DISCUSSION}

This research consists of 4 stages, the first stage is problem identification consisting of Literature Review, Interview, Focus Group Discussion, Questionnaire, and data collection[14]. In identifying the problem, the research question is features needed to build a national public transportation driver behavior assessment model[15], The second stage is Model design where the model is designed using use-case diagrams and class diagrams, while the questions asked in the research design are is "How to build a national public transportation driver behavior assessment model?" The third stage is Implementation, using PHP and Mysq1[16]. The fourth stage is system evaluation, using User Acception test, Black bock testing, White Box testing, and the research question posed is "How to test a national public transportation driver behavior assessment model?"

The research model carried out is the usage of KKNI rules Indonesian National Framework Qualification, which includes the Competency Standards for Graduates (SKL)[17], regarding motorized drivers, the calculation is done using the Decision Support System, namely AHP, and updating driver data[22], then the rules are made (Rule based system)[23]. The results of AHP calculations and the combination with the Rule based system, used to seta recommendation for the driver, such as having ethics and courtesy in driving[23], controlled abilities such as expertise in controlling vehicles both stopping and running, mastered knowledge, such as knowledge of vehicles, rights and responsibilities such as having responsibility for passenger safety. For the description of the flow Diagram is depicted in Figure 1

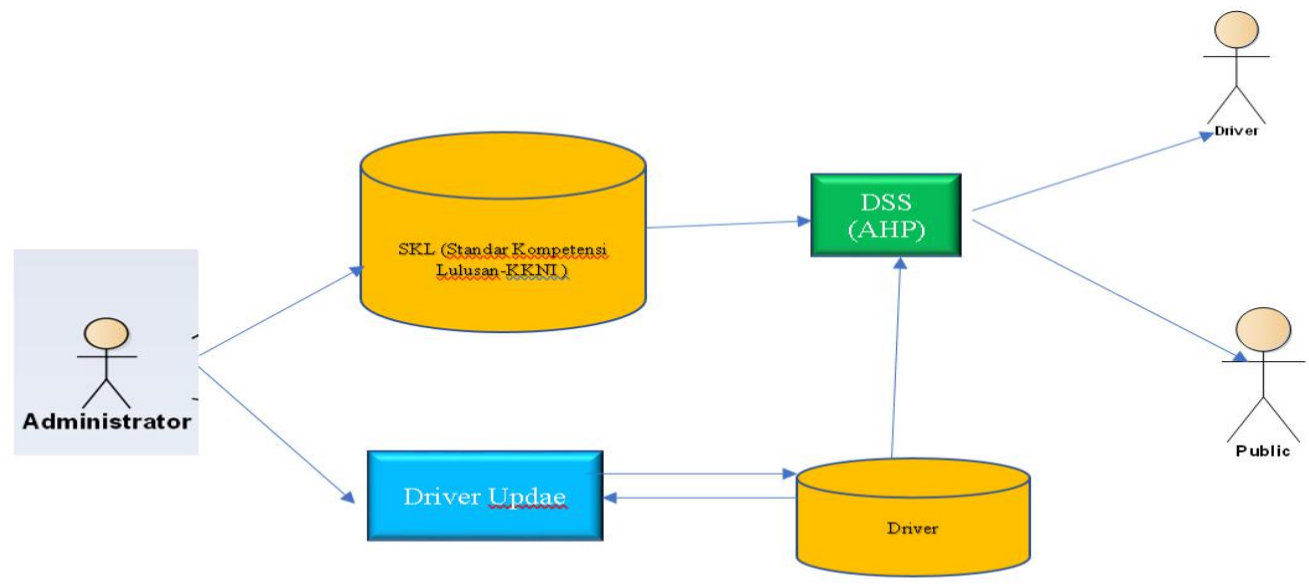

Fig 1. Flow Diagram 
The second stage is model design, the model design used is Use Case Diagrams and Class Diagrams. Modeling using the Use Case Diagram can be seen in Figure 2 below.

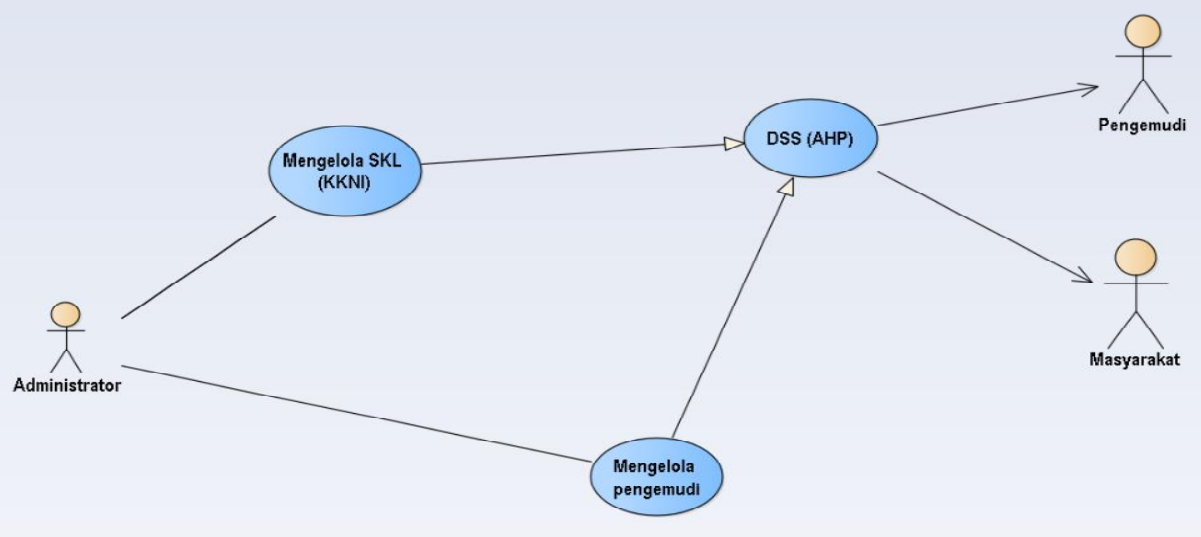

Fig 2. Driver Use Case Diagram

The next stage is designing a Class Diagram consisting of a driver's data base that has an ID number, address, name, place \& date of birth, input into the SKL system which consists of 4 competency features, namely the first competency feature, the attitude of values, abbreviated as Uk1, the second feature is the feature ability in the field of work abbreviated as UK2, the third competency feature is knowledge mastered abbreviated as UK3, the fourth feature is rights and responsibilities abbreviated as UK4[24]. UK1 consists of 6 competency elements, so it is called UK1EK1 to UK1EK6, UK2 consists of 27 competency elements so it is called UK2EK1 to UK2EK27, UK3 consists of 6 competency elements so it is called UK3EK1 to UK3EK6 and UK4 consists of 2 competency elements namely UK4EK1 to UK4EK2. From the KKNI rules then create a database on the Rule Base. See the above descriptions in Figure 3[25].

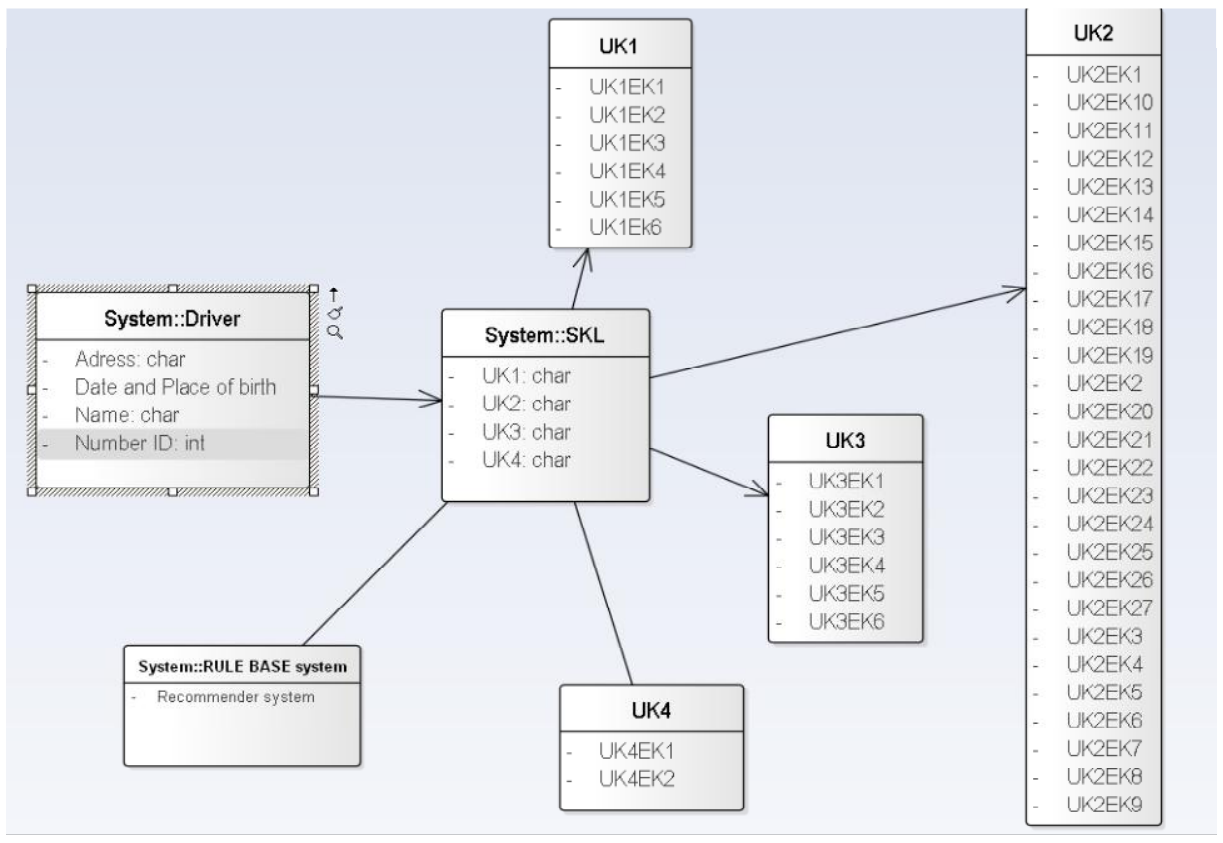

Fig 3. Class Diagram of the Driver 


\section{Conclusion}

The conclusion is to answer the first and second research questions. The answer to the first research question is "that the features needed to build a driver's behavior assessment model are in accordance with the criteria for KKNI-based drivers which consist of 4 assessment parameters, namely attitudes and values abbreviated as UK1, Ability in the field of work abbreviated as UK2, knowledge mastered abbreviated as UK3 and rights and responsibility is abbreviated as UK4". The answer to the second research question is "to design a model made in the form of Use-case diagrams and class diagrams". As Depicted in figure 2 and figure 3

\section{REFERENCES}

[1] N. K. Dewi and A. S. Putra, "Perkembangan Gamification dan Dampak Game Online terhadap Jiwa Manusia di Kota Pintar DKI Jakarta," Jurnal Informatika Universitas Pamulang, vol. 5, no. 3, pp. 315-320, 2020.

[2] N. K. Dewi and A. S. Putra, "SISTEM PENUNJANG KEPUTUSAN PENERIMAAN KARYAWAN BARU DENGAN ALGORITMA GREEDY," Jurnal Visualika, vol. 6, no. 2, pp. 154-160, 2020.

[3] N. K. Dewi, I. Mulyana, A. S. Putra and F. R. Radita, "Konsep Robot Penjaga Toko Di Kombinasikan Dengan Pengendalian Virtual Reality (VR) Jarak Jauh," IKRA-ITH INFORMATIKA: Jurnal Komputer dan Informatika, vol. 5, no. 1, pp. 33-38, 2020.

[4] N. K. Dewi and A. S. Putra, "Decision Support System for Head of Warehouse Selection Recommendation Using Analytic Hierarchy Process (AHP) Method," Prosiding International Conference of Universitas Pekalongan, pp. 1-12, 2021.

[5] N. K. Dewi and A. S. Putra, "LAW ENFORCEMENT IN SMART TRANSPORTATION SYSTEMS ON HIGHWAY," Proceedings International Conference onEducation of Suryakancana 2021, pp. 321-326, 2021.

[6] N. K. Dewi and A. S. Putra, "Prosiding International Conference of Universitas Pekalongan," Prosiding International Conference on Education of Suryakancana 2021 (ICONNECTS 2021), pp. 321-326, 2021.

[7] N. K. Dewi, . B. H. Irawan, E. Fitry and A. S. Putra, "Konsep Aplikasi E-Dakwah Untuk Generasi Milenial Jakarta," IKRA-ITH INFORMATIKA: Jurnal Komputer dan Informatika, vol. 5, no. 2, pp. 26-33, 2020.

[8] A. S. Putra, "Konsep Kota Pintar Dalam Penerapan Sistem Pembayaran Menggunakan Kode QR Pada Pemesanan Tiket Elektronik," TEKINFO Jurnal Ilmiah Teknik Informatika, vol. 21, pp. 1-15, 2020.

[9] A. S. Putra, "Analisa Dan Perancangan Sistem Pembelian Makanan Di Restoran Pada Masa Pandemic Coronavirus Disease 2019 (Covid-19)," Jurnal Esensi Komputasi ( Jurnal Esensi Sistem Komputer dan Informasi ), vol. 4, no. 2, pp. 10-15, 2020.

[10] M. S. Hartawan, A. S. Putra and A. Muktiono, "Smart City Concept for Integrated Citizen Information Smart Card or ICISC in DKI Jakarta," International Journal of Science, Technology \& Management, pp. 364-370, 2020.

[11] A. S. Putra, "Efektifitas Sistem Jalan Underpass untuk Kota Pintar DKI Jakarta," Jurnal Informatika Universitas Pamulang, vol. 5, no. 3, pp. 220-227, 2020.

[12] A. S. Putra and L. H. S. W. Harco , "Intelligent Traffic Monitoring System (ITMS) for Smart City Based on IoT Monitoring," Indonesian Association for Pattern Recognition International Conference (INAPR) IEEE, pp. 161-165, 2018.

[13] A. S. Putra, L. H. S. W. Harco , S. A. Bahtiar , T. Agung, . S. Wayan and H. K. Chu-, "Gamification in the e-Learning Process for children with Attention Deficit Hyperactivity Disorder (ADHD)," Indonesian Association for Pattern Recognition International Conference (INAPR) IEEE, pp. 182-185, 2018.

[14] A. S. Putra, "Peran Sosial Media Sebagai Media Dakwah Di Zaman Pandemic Virus Corona Atau Covid 19 Di Indonesia," Panangkaran: Jurnal Penelitian Agama dan Masyarakat, pp. 1-12, 2021.

[15] A. S. Putra, "Penerapan Konsep Kota Pintar dengan Cara Penerapan ERP (Electronic Road Price) di Jalan Ibu Kota DKI Jakarta. Jurnal Informatika Universitas Pamulang, 5(1), 13-18.," Jurnal Informatika Universitas Pamulang, 5(1), 13-18., pp. 13-18, 2020.

http://ijstm.inarah.co.id 
[16] A. S. Putra, "Teknologi Informasi (IT) Sebagai Alat Syiar Budaya Islam Di Bumi Nusantara Indonesia," Seminar Nasional Universitas Indraprasta ( SINASIS ), pp. 200-215, 2020.

[17] A. S. Putra, " "Smart City : Ganjil Genap Solusi Atau Masalah Di DKI Jakarta"," Jurnal IKRA-ITH Informatika Vol 3 No 3, ISSN 25804316 , 2019.

[18] D. N. M. A. A. P. J. I. D. H. S. Y. C. Arman Syah Putra, "“Examine Relationship of Soft Skills, Hard Skills, Innovation and Performance: the Mediation Effect of Organizational Le," IJSMS, pp. 27-43, 2020.

[19] V. Valentino, H. S. Setiawan, . A. Saputra, Y. Haryanto and A. S. Putra, "Decision Support System for Thesis Session Pass Recommendation Using AHP (Analytic Hierarchy Process) Method," Journal International Journal of Educational Research \& Social Sciences, pp. 215-221, 2021.

[20] D. D. A. P. Riani Muharomah, "“Analisis Run-Off Sebagai Dampak Perubahan Lahan Sekitar Pembangunan Underpass Simpang Patal Palembang Dengan Memanfaatkan Teknik Gis"," 2014.

[21] I. Ramadhan, A. Kurniawan and A. S. Putra, "Penentuan Pola Penindakan Pelanggaran Lalu Lintas di DKI Jakarta Menggunakan Metode Analytic Network Process (ANP)," IKRA-ITH INFORMATIKA: Jurnal Komputer dan Informatika, vol. 5, no. 1, pp. 51-57, 2020.

[22] A. S. Putra, "“Penggabungan Wilayah Kota Bekasi Dan Kota Tangerang Ke Wilayang Ibu Kota DKI Jakarta Berdasarkan Undang-Undang Nomor 23 Pasal 32 Tahun 2019 Dapat Membantu Mengwujudkan DKI Jakarta Menjadi Kota Pintar"," Jurnal IPSIKOM VOL 7 No. 2, 2019.

[23] A. S. Putra, L. H. S. W. Harco , L. G. Ford , . S. Benfano and A. Edi , "A Proposed surveillance model in an Intelligent Transportation System (ITS)," Indonesian Association for Pattern Recognition International Conference (INAPR) IEEE, pp. 156-160, 2018.

[24] A. S. Putra and . R. R. Fatrilia, "Paradigma Belajar Mengaji Secara Online Pada Masa Pandemic Coronavirus Disease 2019 (Covid-19)," MATAAZIR: Jurnal Administrasi dan Manajemen Pendidikan, pp. 49-61, 2020.

[25] A. S. Putra, " "Smart City : konsep Kota pintar di DKI Jakarta"," Jurnal TEKINFO, Vol 20, No 2, Hal 1-111, ISSN 1411-3635, 2019.

[26] A. S. Putra, H. L. H. S. Warnars, B. S. Abbas, A. Trisetyarso, W. Suparta and C.-. Ho Kang, "“Gamification in the eLearning Process for children with Attention Deficit Hyperactivity Disorder (ADHD)"," 1st 2018 Indonesian Association for Pattern Recognit INAPR, pp. 182-185, 2019. 